\title{
Chapter 4 \\ Do Water Management and Climate-Adapted Management of Wetlands Interfere in Practice? Lessons from the Biebrza Valley, Poland
}

\author{
Mateusz Grygoruk and Tomasz Okruszko
}

\begin{abstract}
In this chapter the authors deal with the implementation of Water Framework Directive in the catchment of the Biebrza River (north-east Poland) that covers $7,120 \mathrm{~km}^{2}$. Special attention was paid to the context of conservation of riverine and wetland ecosystems facing pressures driven by the climatic change. Measures foreseen by the National Water-Environment Programme for the catchment of Biebrza are analysed in order to reveal whether the actions planned, expressing the implementation of Water Framework Directive, anticipate potential pressures originating from the observed and defined, climate-related pressures such as increasing frequency of summer flooding, ongoing decrease in summer sums of precipitation and increasing frequencies of extremely high summer rainfalls. The DPSIR feedback loops presenting selected relations between the climate-related pressures and potential negative responses of geoecosystems of the Biebrza catchment are described in order to verify whether the measures implemented aimed at conservation and improvement of the state of water bodies and waterdependent ecosystems are capable for assuring their good status. Basing upon the observations and facts analysed, the authors derive lessons learnt from the process of Water Framework Directive implementation, showing that the improvement of allocation of funds to the water management actions is needed in order to assure good ecological status of aquatic and wetland ecosystems, concerning qualitative and quantitative elements of the water-related environments, facing direct and indirect climate-related pressures.
\end{abstract}

Keywords Biebrza - Wetlands - Water framework directive - Climate change • DPSIR

M. Grygoruk $(\square) \cdot$ T. Okruszko

Department of Hydraulic Engineering, Warsaw University of Life Sciences-SGGW,

ul. Nowoursynowska 159, 02-776 Warsaw, Poland

e-mail: m.grygoruk@levis.sggw.pl

(C) The Author(s) 2015

S. Ignar and M. Grygoruk (eds.), Wetlands and Water Framework Directive,

GeoPlanet: Earth and Planetary Sciences, DOI 10.1007/978-3-319-13764-3_4 


\subsection{Introduction}

Environmental management of the complex systems, such as wetlands, requires anticipation of the broadest possible set of factors that may induce status and responses of ecosystems. This includes hydrological processes responsible for the continuity of water supply and drainage, human-related actions oriented at economic use of wetlands, geomorphology and soil-forming processes as well as the climate and global environmental dynamics. Existing legal agents require consideration of the environmental and human-enforced challenges influencing the environment. Water Framework Directive (WFD; Directive 2000/60/EC of the European Parliament and of the Council of 23 October 2000 establishing a framework for Community action in the field of water policy) put special attention to the achievement of a good status of waters and water related ecosystems. Habitat Directive (HD; European Council Directive 92/43/EEC) and Bird Directive (BD; European Council Directive 2009/147/EC) have referred to the conservation of the total environment in the most valuable zones, by the implementation of protection plans, assuring stakeholders' awareness. National and regional regulations as to the environmental protection, by incorporation of the European law, assure implementation of particular procedures oriented at minimization of possible negative responses of the elements of the environment to the defined pressures. Finally, the national plans oriented at adaptation to the changing climate (ACC) require to be considered in the general approaches of the integrated environmental management.

However, although the legislation regarding environmental management appears to be comprehensive enough to anticipate and mitigate the negative effects of nearly all possible stressors, the implementation of integrated actions reflecting legal requirements of environmental policy seems to fail, especially if the local scale is considered (Biereżnoj-Bazille and Grygoruk 2013). This situation originates from the fact that bodies responsible for implementation of WFD, HD, BD and ACC undertake non-integrated actions. Inconsistencies are reported in the cases of flood risk management implemented as dredging the rivers of a high environmental conservation status, intensification of agricultural practices that affect the environment in the areas covered by Natura 2000, or in the application of measures which, although aim at conservation of good status of species and habitats, do not consider prospective stressors originating in the impacts of a changing climate. Such inconsistencies in the implementation of environmental policy allow to foresee certain risks for a successful environmental management and therefore should be unraveled in order to enhance the potential effects of ecosystem conservation and restoration. Especially facing the fact, that the future of the environment of European wetlands was sketched as critically related to the climatic change (Okruszko et al. 2011; Schneider et al. 2011).

The main aim of this chapter is to analyze the status of WFD implementation in reference to conservation and assuring appropriate ecological status of rivers and water-dependent ecosystems in the catchment of the Biebrza (NE Poland), facing direct and indirect environmental impacts of climate change. We provide a 
drivers-pressures-state-impact-response (DPSIR) analysis referring to the defined pressures driven by the changing climate, where the main impact concerned is the threat to the good status of the Biebrza catchment's rivers and wetlands which are substantial elements of biodiversity conservation in the Central Europe. Referring to the feedback relations defined, we interpret the undertaken and planned actions that reflect WFD implementation and discuss whether they cover the set of required actions originating from the deteriorating status of aquatic and water-dependent ecosystems. We compare the allocation of funds in the set of the WFD-related actions in order to assess which types of actions have priorities and which of them are likely to remain challenges for good status of rivers and related ecosystems. Finally we provide concise lessons learnt from the analysed process of WFD implementation in the catchment scale, considering climate change impacts, protection of species and habitats, and defined conflicts occurring at the interface of water management, agriculture and environmental conservation.

\subsection{Physiographic Outline of the Study Area}

The catchment of the Biebrza river (Fig. 4.1), covering 7,120 $\mathrm{km}^{2}$, which is nearly $2.5 \%$ of the area of Poland, consists of variable landscapes. Upper, northernmost parts of the catchment belong to the Baltic Lakelands of a fresh glacial relief, formed approximately 10,000 years BC whilst the eastern ridges of the catchment are located within the landscapes formed by the older glaciations (ca. 120,000 years BC, Żurek 1984). The core of the catchment is the vast lowland depressionBiebrza Valley, that due to unique hydrogeological and ecological conditions consists of well-preserved wetlands of unique ecological status in the scale of the continent (Wassen et al. 2006). Elevations in the analysed area vary from some $310 \mathrm{~m}$ a.s.l. to some $90 \mathrm{~m}$ a.s.l., making the area of research a lowland geoecosystem. Predominantly mineral, tilly and sandy soils cover the majority of the area of catchment, but the Biebrza Valley is one of the broadest coherent extents of peatlands in Europe. Average annual air temperature reaches some $5.7^{\circ} \mathrm{C}$ with the extremes recorded in July (some $33^{\circ} \mathrm{C}$ ) and February (some $-25^{\circ} \mathrm{C}$ ), which allows to classify the climate of the Biebrza Valley as temperate, with strong continental influences (Jaszczuk 2014). Average annual sum of precipitation in the catchment of Biebrza calculated on the basis of rainfall records from 1951 to 2010 reach some $556 \mathrm{~mm}$, with the maximums noted in summer (May-September; $315 \mathrm{~mm}$ ) (Jaszczuk 2014). Average potential evapotranspiration in the catchment of Biebrza calculated with the Thornthwaite's algorithm (Wojciechowski 1968) for the data from 1961 to 2010 exceeds $560 \mathrm{~mm}$ (Jaszczuk 2014), which allows to state that water resources of the catchment of Biebrza valley are nearly equally balanced and thus require monitoring and actions in order to assure appropriate amounts of water to the final users: society, economy, agriculture and - primarily - the environment. Average outflow from the catchment of Biebrza reaches some $33 \mathrm{~m}^{3} / \mathrm{s}$, varying up to some $600 \mathrm{~m}^{3} / \mathrm{s}$ during the most important flood events (Grygoruk et al. 2013b). 


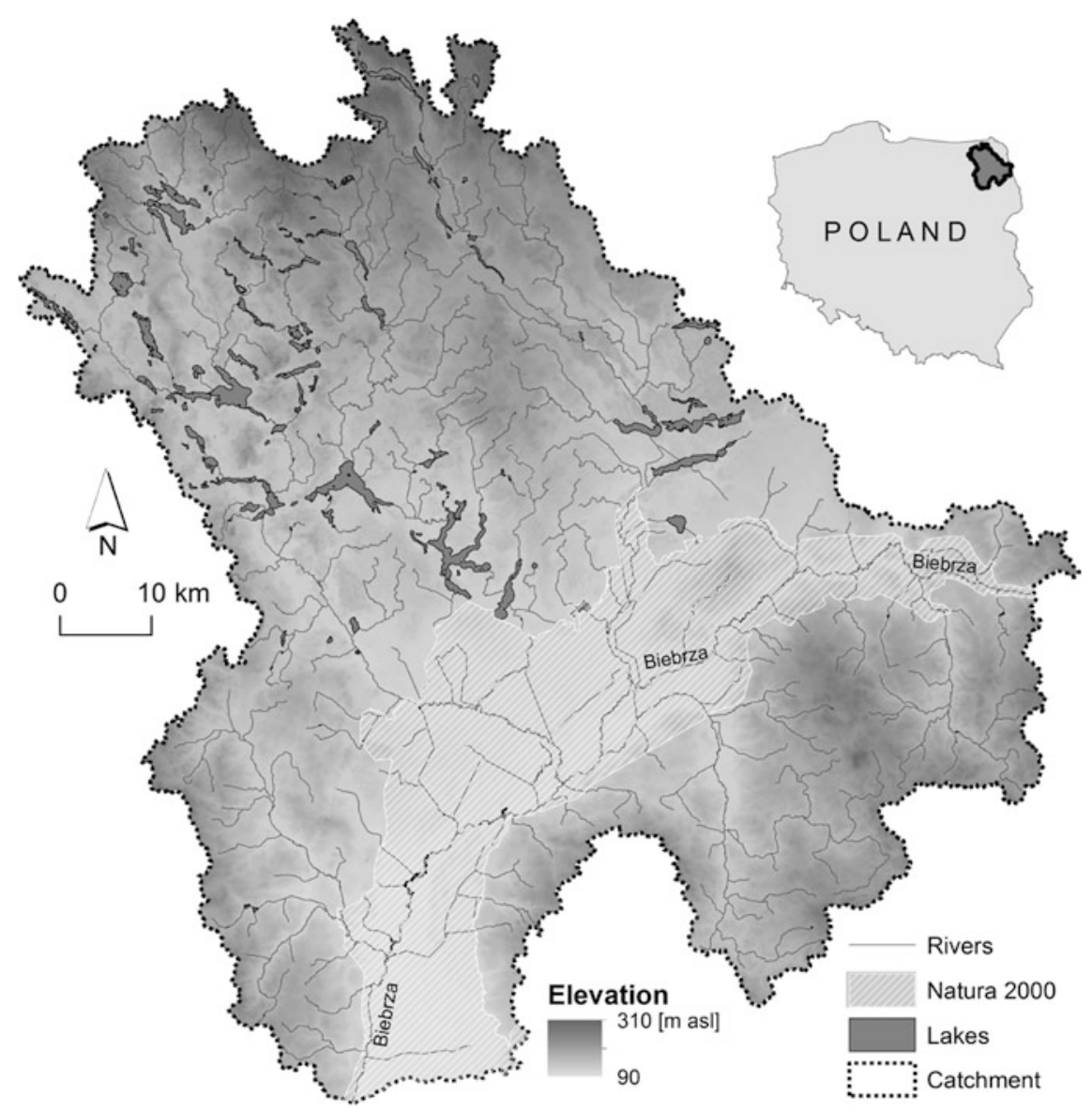

Fig. 4.1 Study area-catchment of the Biebrza river: water bodies and environmental conservation

Hydrological features of the Biebrza Valley as well as recorded dynamics of floods allow to conclude that inundation remains an important yet frequent phenomenon (Grygoruk et al. 2013a; Ignar et al. 2011). Among the most valuable and important water-dependent ecosystems in the catchment of Biebrza there are eutrophic oxbow lakes, fens of the type Caricion davallianae (concentrated both in the Biebrza Valley and in the random locations in the fresh glacial landscape in the northwestern part of the catchment), bogs, riparian Alder forests Ribeso nigri-alnetum, reedbelts and riparian sedge communities Magnocaricion (Wassen et al. 2006).

Water bodies belonging to the catchment of Biebrza river are managed by different authorities, of which the most important are Regional Water Management Authority in Warsaw (in Polish: Regionalny Zarząd Gospodarki Wodnej; RZGW), Voivodeship Board of Land Reclamation and Hydrotechnics in Białystok 
(in Polish: Wojewódzki Zarząd Melioracji i Urządzeń Wodnych w Białymstoku, WZMiUW), Biebrza National Park (BNP) and - to certain limited extent-local subjects of national administration-communes. Whilst to the competences of the first three institutions (RZGW, WZMiUW and BNP) belongs the implementation of WFD, communes are mostly responsible for the maintenance of ditches and minor rivers and streams and WFD, although should, is not directly considered.

\subsection{Climate Change, Water Management and Ecosystems' Response}

Climatic change impacts to the ecosystems of the Biebrza Valley, although already defined as a challenge for valuable wetlands in NE Poland (Grygoruk et al. 2014a; Ignar et al. 2011), has hardly been anticipated so far neither in the environmental conservation management in the basin of the river Biebrza nor in the Water Framework Directive implementation in this area. First steps towards the design and application of climate-adapted management of protected areas of wetlands in this region were done in the Biebrza National Park, by implementing the HABITCHANGE project (Rannow and Neubert 2014) and by preparation of the draft document - Climate Adapted Management Plan for the Biebrza National Park (Grygoruk et al. 2013b). Main findings of the project pointed out that the majority of climate-related threats for valuable wetlands result from the quantitative alterations of water cycle, either as a direct result of naturally evolving hydrological processes (increasing frequency of summer flooding, ongoing decrease in summer sums of precipitation, increasing frequencies of extremely high summer rainfalls) or indirectly, as the reaction of stakeholders on these processes (Grygoruk et al. 2014a).

In order to attempt the assessment of whether the actions implemented reflecting WFD are capable to deal with the prospective defined climate change stressors, the DPSIR matrix of general feedback loops was developed. Such an approach was proven to be a suitable tool in detecting WFD-implementation-related risk assessment (Borja et al. 2006). It anticipates climate-related pressures to habitats (after Grygoruk et al. 2014a) that induce the state of ecosystems, to which the negative impact to be considered in the water management was defined as the "threat to the good status of rivers and wetlands" (Fig. 4.2). The analysis was assumed to reflect the most critical climate-related pressures, which was the observed and projected increased recurrence of extreme hydrological events (summer floods, deep droughts and heavy rainfall events), reduction of the snow pack and the ongoing earlier occurrence of thaw floods and observed and projected general increase of the air temperature in winter. Among the elements of aquatic and wetland ecosystems' state reflecting the defined pressures, there are reactions that origin from the interfaces of economic, social and environmental spheres. First and foremost, climate-related pressures defined result in the negative response of stakeholders: 


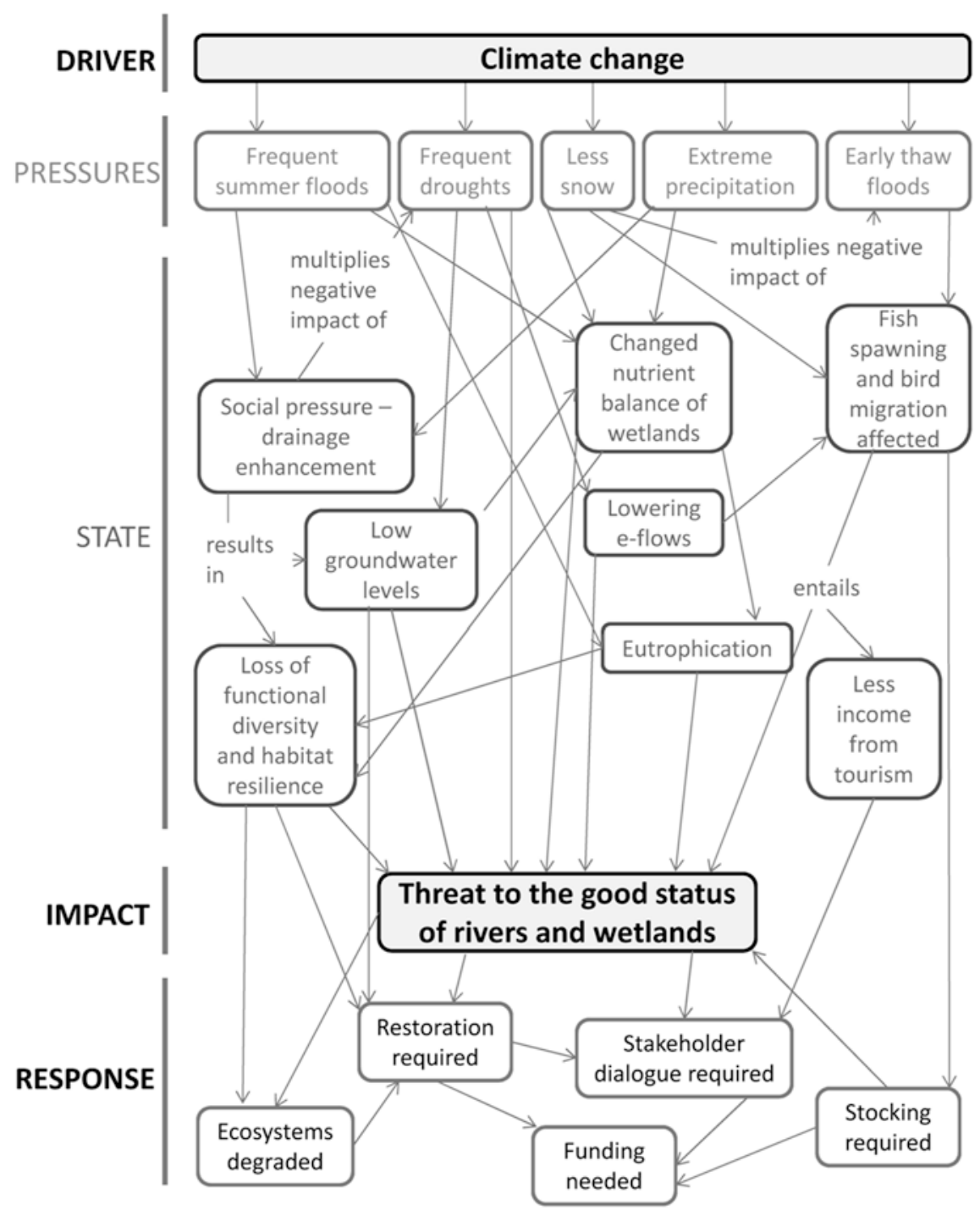

Fig. 4.2 DPSIR loops - defined selected states and responses to the negative impacts of prospective climate change to ecosystems of the Biebrza Valley

frequent flooding, which has much stronger, short-term negative influence to economic use of wetlands (e.g. mowing) than forecasted long-lasting and frequent deep droughts. It is due to the fact that flooding and general high (ground) water level negatively affects the possibility of wetland meadow mowing and hay removal, which reduces farmers' income and underlies complications in agro-environmental schemes implementation. 
High saturation of the soil remains an obstacle for using mechanic gear (tractors and large-track mowers), which-although positive from the environmental perspective (Kotowski et al. 2013) — does not allow the broad areas of wetlands to be maintained by mowing. This particular process forces land users and farmers to mitigate the negative influences of inundation to the local economy, by putting pressure to water managers in order to increase efforts oriented at river dredging and restoration (reconstruction) of the existing networks of ditches (Dembek 2015). This action, directly driven by the climatic factors, observed especially during and after wetter summers, critically affects the status of water bodies (Biereżnoj-Bazille and Grygoruk 2013; Mioduszewski and Okruszko 2012) and might be considered as one of the most important, social-perception-related pressures to aquatic and wetland ecosystems in the basin of the river Biebrza, requiring efforts such as enhanced stakeholder dialogue. Expanding pressures to the enhancement of drainage and river dredging is expected to multiply the effect of summer droughts, which - although recorded in the years 2013 and 2014- have not been considered by water management authorities as a major threat to the ecosystems and water quality.

In the drained parts of the catchment, where peat layers decomposed into muck, the flood-drought balance is expected to affect the soil nutrients' circulation. Frequent saturation of the decomposed peat, either in response to natural phenomena (increasing groundwater level, flooding) or human-related issues (fen rewetting and management of land reclamation systems) interrupts nutrient balance by favoring soluble fractions of phosphorus to be released from organic soils to pore water, groundwater and-finally, in certain geochemical conditions - to surface waters (Zak et al. 2010). In result, the eutrophication of aquatic and wetland ecosystems should be expected and mitigated. For mineral-rich, but nutrient-poor fen ecosystems, the eutrophication entails the switch in the geochemical limitations of biocenoses: habitats which have formerly been not suitable for species requiring eutrophic conditions are projected to be exposed for the loss of their resilience and though - to the evolution from oligotrophic to eutrophic wetlands. In result, habitats of the high conservation status such as Caricion davallianae are exposed to climateand water-management-related risk of deterioration. Consequently-limited resilience of fens staying under the influences of eutrophic waters originating from resaturated muck soils is suspected underpins a loss of their natural capacity to buffer the external pressures, which altogether induces these ecosystems to be vulnerable to any environmental disturbances. The response of the aquatic and wetland ecosystems in the cases analysed (Fig. 4.2) will be negative in both shortand long-run and will reflect with the requirement of ecosystem restoration.

Increasing frequency of droughts is likely to affect the environmental flows in the whole catchment, which is expected to be critically important in the headwater reaches of the area analysed, where river water is dammed in lakes and is collected in order to refill the fishponds. The affected environmental flows would not have that significant influence for the downstream reaches of rivers, especially the 
Biebrza and its tributaries flowing in the near neighborhood of the Natura 2000 sites, if the hydromorphology of rivers was properly maintained. Reported conflicts at the interface of river management and the requirements of environmental conservation (Biereżnoj-Bazille and Grygoruk 2013; Mioduszewski and Okruszko 2012) showed, however, that in cases of certain rivers (e.g. Brzozówka, Klimaszewnica), where hydromorphology of river channels was decently disrupted as a result of social-demand of river management, the decrease of volumes of lowest flows (and though - the environmental flows) can be expected and underlay a significant risk to aquatic species. Hence, also in the dimension of river management implemented so far in the area of research, regarding possible mitigation of climate-affected increasing recurrence of droughts, no actions were taken in order to minimize the negative effects of climate-related pressures to ecosystems' state.

Among the most significant, climate-driven pressures to biota in the area analysed there are temporal changes of the spring thaw floods (Ignar et al. 2011; Grygoruk et al. 2013b) which were defined as a threat to migratory birds and fish spawning. Due to the earlier occurrence of spring floods and projected decrease in their volume and duration (Grygoruk et al. 2014a), the role of Biebrza Valley as a stopover spot for waterfowl birds is expected to lose its relevance. Moreover, if the balance of flooded and dry areas was considered as an important aspect of biotopes for certain species of birds of prey (e.g. Spotted Eagle and Lesser Spotted Eagle), this climate-related process may affect the condition of their population (Maciorowski and Mirski 2014). In a long run, the affected populations of migratory birds in the Biebrza Valley are expected to result in the decrease of tourism intensity, and though - a partial loss of the international importance of Biebrza Wetlands. In the case of fish, especially the European pike (Esox lucius), and concerning the fact that the spring floods were observed and are expected to keep decreasing in terms of volume and duration, the lack of appropriate spawning habitats (flooded meadows) may invoke the need of stocking. So far, as the population of fish in the Biebrza river and its principal tributaries (lower Ełk, lower Jegrznia) developed with no significant genetic and structural disturbances originating from the artificial fish supply, stocking was not required and considered environmentally negative for the native populations. Facing the pressures originating in changing climate, fish stocking and the related restoration of aquatic habitats and spawning grounds may be required in order to mitigate the negative impacts related to the altered flow regime.

Presented feedbacks of climate-induced challenges to aquatic and wetland ecosystems require special attention of water management authorities. Focusing at so-far planned and implemented actions for the Biebrza Catchment originating from the National Water-Environment Programme, one can conclude that a vast majority of threats originating in climatic drivers remains - however - not anticipated. 


\subsection{Actions of the National Water-Environment Programme for the Catchment of Biebrza}

National Water-Environment Programme (NWEP; in Polish: Program Wodno-Środowiskowy Kraju) in the scale of both the whole country of Poland and of the Biebrza Catchment (NWEP 2010), along with the Catchment-scale Water Management Plans remains one of the principal planning documents in water management. It directly reflects the implementation of WFD in terms of necessity of preparation and application of measures oriented at achievement of the environmental goals required by this regulation (Table 4.1). This document defines and describes basic and additional measures required for the enhancement or conservation of the good status of waters in particular water regions of Poland. By definition, the Water-Environment Programme anticipates quantitative, qualitative, social and economic measures oriented at the assurance of appropriate implementation of WFD's environmental goals. Comprehensive approach of the National Water-Environment Programme is geared towards

Table 4.1 Actions implemented by the responsible authorities reflecting the requirements National Water-Environment Plan in the region of the catchment of Biebrza in order to assure the good status of aquatic and wetland ecosystems (NWEP 2010)

\begin{tabular}{|c|c|}
\hline Group of actions & Particular actions \\
\hline \multirow[t]{6}{*}{ Sewage management } & Sewage system extension and modification \\
\hline & Construction of small sewage treatment plants \\
\hline & Collection of leakages from industrial areas \\
\hline & Construction of new sewage treatment plants \\
\hline & Control of the sewage collection agendas and plans \\
\hline & $\begin{array}{l}\text { Inventory of septic tanks and individual sewage } \\
\text { containers }\end{array}$ \\
\hline \multirow[t]{2}{*}{ Waste management } & Liquidation of illegal waste disposals \\
\hline & Modernization of waste disposals and landfills \\
\hline \multirow[t]{3}{*}{ Agriculture } & Popularization of modern agricultural practices \\
\hline & Capacity building-agro-environmental schemes \\
\hline & Popularization of sustainable agriculture \\
\hline \multirow[t]{2}{*}{ Water management } & $\begin{array}{l}\text { Preparation of the Regional Regulations of use of } \\
\text { Waters }\end{array}$ \\
\hline & Construction of a fish-pass \\
\hline Spatial planning & Preparation of the local spatial planning regulations \\
\hline $\begin{array}{l}\text { Environmental conservation-Natura } \\
2000\end{array}$ & Preparation of the Natura 2000 protection plans \\
\hline \multirow[t]{2}{*}{ Forestry } & $\begin{array}{l}\text { Implementation of the regional afforestation } \\
\text { programs }\end{array}$ \\
\hline & Afforestation of abandoned agricultural lands \\
\hline \multirow[t]{2}{*}{ Environmental conservation } & $\begin{array}{l}\text { Enhancement of the capacity of environmental } \\
\text { conservation }\end{array}$ \\
\hline & Day-to-day environmental conservation \\
\hline
\end{tabular}


the increase of sewage and waste management, aims at promotion of sustainable agriculture, spatial planning, forestry and environmental conservation as well, describing particular individual actions located in defined parts of the catchment. Actions described, reflecting the planning and application of water resources management by the National Water-Environment Programme for the region of the catchment of Biebrza, are divided into certain groups. Altogether there are 275 actions defined. Analysis of this document revealed that the major attention is put to the conservation and increase of qualitative status of water bodies (Table 4.1, Fig. 4.3a). Sewage and waste management measures are oriented in principle at the extension and enhancement of municipal sewage systems, collection of leakages from the industrial sites, construction of sewage treatment plants, inventories of septic tanks and the liquidation of the illegal waste disposals and landfills combined with the restoration of the present ones. Comparing to the other actions defined by the National Water-Environment Programme referring to the space of the catchment of the river Biebrza, such as the ones reflecting agriculture, direct water management (e.g. planning of the regional conditions of water use), spatial planning, forestry and environmental conservation with special regard to Natura 2000, actions oriented at sewage and waste management cover more than a half of all the actions described by this document (Fig. 4.3a).

Actions referring to the agriculture, provided by the National Water-Environment Programme, aim at activities implementing the stakeholder dialogue, including popularization of modern, competitive and sustainable agricultural practices and capacity building towards the implementation of the European Union's agro-environmental schemes. Direct measures related to water management in the catchment of Biebrza are oriented at preparation of Regional Regulations of use of Waters (in Polish: Warunki Korzystania z Wód Regionu Wodnego). Worth noticing is the single action oriented at the recovery of longitudinal river continuity, which is the fish-pass construction in the course of the river Ełk (Rudzki Canal), in the close neighborhood of the Biebrza Valley. One can regret that among the 275 actions there is only one measure of this type planned, especially facing the number of functioning weirs, dams and spillways that efficiently affect longitudinal ecological continuity of aquatic ecosystems in the catchment of Biebrza.

Still, however, the planned fish pass is to be constructed with the newly-designed weir, which does not allow to conclude that particular actions were undertaken in order to bring back the former longitudinal continuity of rivers in the region analyzed. In the other words - the negative role of obstacles in the courses of rivers in the catchment of Biebrza was not anticipated, so their influence on fish and macroinvertebrates is not going to be mitigated in result of the WFD implementation in this area. Although the wish to construct one fish pass allows to foresee growing interest of water-policy implementing authorities in assuring ecological connectivity of river continua, the major attention should be paid to multiple constructions (weirs and dams) which were designed in the past and underpin the fragmentation of river continua in the region.

National Water-Environment Programme provides also the measures reflecting spatial planning, expressed as preparation of local strategies. In terms of reflectance 


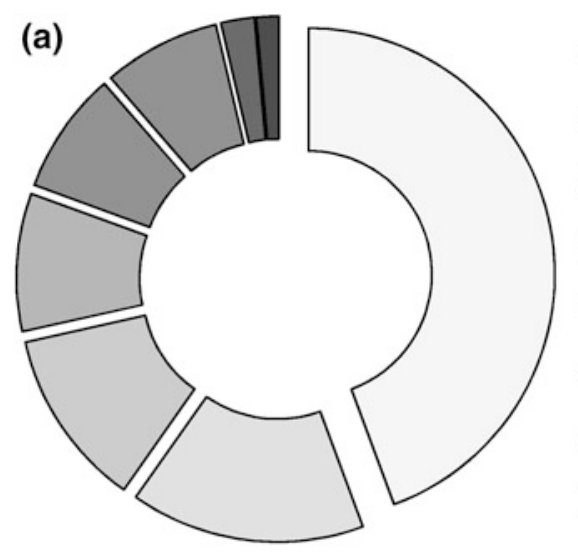

$\square$ Sewage management

口Waste management

$\square$ Agriculture

$\square$ Water management

๑Spatial planning

口Environmental conservation - Natura2000

口Forests

๑Environmental conservation

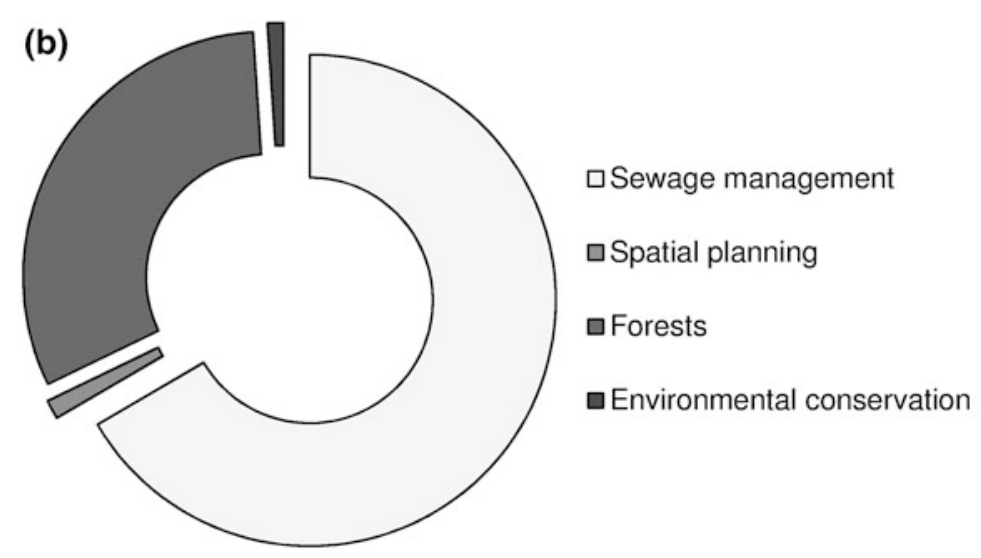

Fig. 4.3 Groups of actions planned in order to implement the National Water-Environmental Program for the region of the Biebrza catchment; a number of measures in particular groups of actions; $\mathbf{b}$ total costs of actions (referred to the total budget of NWEP implementation in this regionas specified in the data of the NWEP 2010)

of climate- and environmental-conservation-related challenges, the most important in this level appears to be to assure that the floodplains are not planned as the space for the settlements' development. Actions reflecting environmental conservation, with special focus to the BD and HD implementation, emphasize preparation of the Natura 2000 areas protection plans and pay attention to the day-to-day environmental management. Such actions are expected to benefit the local dimensions of climate-related management adaptation, as the day-to-day management in protected areas should anticipate challenges of a stakeholder dialogue by inducing their positive attitudes towards the local-scale influences of the global climatic changes.

Actions prescribed by the NWEP in the context of the catchment of Biebrza, oriented at sustainable forestry, predominantly promote at afforestation of the abandoned agricultural lands. This sort of actions, although desirable within the extents of mineral soils, may provide the hydrological stress for mire meadows, 
especially in the periods of drought (Grygoruk et al. 2014b), which are foreseen to occur more frequently in the future.

Implementation of the National Water-Environment Programme requires funding. Noteworthy, according to the information given in the NWEP (2010), only four out of eight groups of actions have particular budget assigned (Fig. 4.3b). The most significant share of funding is related to the sewage management which also expresses the high priority of this group of actions (Fig. 4.3a). Surprisingly, the actions related to the afforestation have also received the significant financial contribution which may be considered unproportional, if the number of all the actions provided by the National Water-Environment Programme was considered. Remaining actions foreseen in this document are to be implemented within the existing budgets of local authorities and external projects and no additional funding originating from the pure implementation of the WFD implementation is planned. Among them there are actions oriented at the enhancement of agriculture, direct water management and environmental conservation. Analyzing the structure and content of NWEP (2010) one can conclude that no particular attention is paid to the potential climate-related challenges to WFD implementation.

\subsection{What Is Missing?}

The major flaw of the set of actions analysed above is that majority of proposed measures are economy-oriented (e.g. majority of funding is related to the forthcoming actions consisting of the construction works such as sewage treatment systems). Actions related to the improvement of the environmental quality which deteriorated as a response of ecosystems to the former stresses, such as hydromorphological changes of river channels (dredging, land reclamation, lowering water levels), are in general omitted. This reflects the finding of Dembek (2015) who claims that the balance of water-related policies should switch from the anthropocentric approaches towards the attitudes considering the environment as a priority. In this regard one can also conclude that the climate-related threats of the ecosystems are not anticipated by the National Water-Environment Programme (NWEP 2010). No direct attention is paid to the prospective changes in the recurrence of floods and droughts, which, together with stationary approach to the environmental flows, may result in inevitable changes of ecosystems dependent on groundwater and baseflow (among them there are all aquatic ecosystems that keep to be under stress in low flow periods). The fact that the regional plans of irrigation and drainage, which in general assume the improvement of the function of draining role of land reclamation systems and rivers (and thus may multiply the negative effects of droughts) also do not keep to be in the accordance with the requirements of WFD, HD, BD and - surprisingly - also with the National Water-Environment Programme. This was already proven in numerous reports (e.g. Biereżnoj-Bazille and Grygoruk 2013; Mioduszewski and Okruszko 2012). Wishing to keep aquatic ecosystems of the region of Biebrza Catchment in a good ecological status, assuring their resilience to prospective climate-related 
pressures, water management authorities should foresee actions oriented at restoration of formerly degraded wetlands and rivers, providing appropriate funding. So far, in the perspective of environmental policy implementation and at the interface of environmental conservation and management of valuable ecosystems, we conclude that the regulations resulting mostly from the WFD, HD and BD are not interrelated in their implementation, which causes vast selectivity in implementations of measures and thus - results only in the partially positive responses of the managed wetlands and aquatic ecosystems.

\subsection{Lessons Learnt and Implications for the Management}

1. Contemporary environmental management programmes resulting from Water Framework Directive as well as from the Natura 2000 regulations, either do not anticipate climatic change at all (Water-Environment programme for the Biebrza Catchment) or consider this phenomenon to the very limited extent (Natura 2000 management plans). Although regulations seem to be strict and comprehensive enough in order to assure the adaptation to the prospective climatic change, both implemented so far and planned actions do not reflect anticipation of the impacts of changing climate neither to ecosystems nor to society and local economy.

2. Climatic change and related actions, although normally being considered in the scale of continents and countries, should be presented to local societies as challenges of the local scale in order to assure public acceptance of mitigation and adaptation measures.

3. No interlinks between the water management plans and Natura 2000 protection plans were observed in the region analyzed, especially in terms of climaterelated adaptive management and river continuity (fish passes). Although some actions were undertaken in order to assure restoration of formerly drained wetlands and to restore the continuity of rivers to biota, this type of actions is in general neglected in regional water management policy, requiring to be improved.

4. Reactions of water management authorities to floods and conditions of high water levels are much quicker and influential to the environment than the ones oriented towards the droughts. So far no response form water management authorities occurred in the catchment of the river Biebrza in order to mitigate the negative effects of droughts, for both society and ecosystems. This should be considered as a flaw of the WFD implementation which should anticipate droughts as an important threat for water resources in the environmental (e.g. environmental flows) and socio-economic context (e.g. water supply to agriculture and aquaculture, drinking water supply).

5. The majority of threats to rivers in wetland landscapes originate from the EUsubsidized intensification of grassland farming. It is observed that the degradation of rivers results from social pressures of farmers and land users receiving payments for the so-called sustainable use of wetlands. One can expect that in order to 
enhance the implementation of Water Framework Directive either the form of subsidies should be changed and farmers will be paid for storing water on their wetland meadows, or the future financial perspectives of EU will not cover any payments oriented at the grassland farming. As the latter is a way less possible and further degradation of rivers in agricultural wetland landscape is to be expected, WFD requirements should be emphasized in order to preserve as much rivers in a "good status" as possible. The role of NGOs in this process is crucial.

6. Climatic change projections as well as the designed and implemented climateadapted environmental management plans reach the time horizon 2070-2100. However, one should expect that achieving and sustaining good status of water bodies and related wetland ecosystems can only be reached if appropriate actions resulting from WFD and Natura 2000 legislative recommendations were started immediately, from tomorrow, not being postponed to (nor resulting from) the next financial perspective of the EU. Regardless of the fact that new scientific and research initiatives are beneficial for institutions responsible for environmental management we stress that the actions reflecting conservation and sustainable use of waters and wetlands should originate from the local-scale mechanisms that are well-established in the Natura 2000 and WFD frameworks and are sustainable in terms of implementation, being economically self-sustainable, not being dependent on externally financed projects.

7. Water management and climate-related adaptive management in the Biebrza Catchment do not interfere to the extent that would assure the beneficial implementation of WFD, HD, BD and National Water-Environment Programme to the environment. Revision of the match between the legal requirements and actions undertaken is required.

Open Access This chapter is distributed under the terms of the Creative Commons Attribution Noncommercial License, which permits any noncommercial use, distribution, and reproduction in any medium, provided the original author(s) and source are credited.

\section{References}

Biereżnoj-Bazille U, Grygoruk M (2013) Scale matters: efficiency assessment of EU environmental directives implementation in a local-scale management of protected wetlands in Poland. Sci Ann Danube Delta Inst 19:5-12. doi:10.7427/DDI.19.01

Borja A, Galparsoro I, Solaun O, Muxika I, Tello EM, Wriarte A, Valencia V (2006) The European Water Framework Directive and the DPSIR, a methodological approach to assess the risk of failing to achieve god ecological status. Estuar Coast Shelf Sci 66:84-96

Dembek W (2015) New vision of the role of land reclamation systems in nature protection and water management. In: Ignar S, Grygoruk M (eds) Wetlands and water framework directive: protection, management and climate change, GeoPlanet: Earth and Planetary Sciences. Springer, Berlin

Grygoruk M, Mirosław-Świątek D, Chrzanowska W, Ignar S (2013a) How much for water? Economic assessment and map ping of floodplain water storage as a catchment-scale ecosystem service of wetlands. Water 5(4):1760-1779. doi:10.3390/w5041760 
Grygoruk M, Sienkiewicz J, Hattermann F, Stagl J. (2013b) Climate adapter management plan (CAMP) for Biebrza National Park. HABIT-CHANGE 5.3.1 report, 99 p. (http://www2.ioer. de/download/habit-change/HABIT-CHANGE_5_3_1e_BNP_CAMP_for_Biebrza_NP.pdf)

Grygoruk M, Biereżnoj-Bazille U, Mazgajski M, Sienkiewicz J. (2014a) Climate-induced challenges for wetlands: revealing the background for adaptive management of ecosystems in the Biebrza Valley, Poland. In: Rannow S, Neubert M (eds) Managing protected areas in Central Europe under climate change. Advances in Global Change Research 58, Springer, Berlin. doi:10.1007/978-94-007-7960-0_14

Grygoruk M, Batelaan O, Mirosław-Świątek D, Szatyłowicz J, Okruszko T (2014b) Evapotranspiration of bush encroachments on a temperate mire meadow - a nonlinear function of landscape composition and groundwater flow. Ecol Eng 73:598-609. doi:10.1016/j.ecoleng. 2014.09.041

Ignar S, Maksymiuk-Dziuban A, Mirosław-Świątek D, Chormański J, Okruszko T, Wysocki P (2011) Temporal variability of selected Floyd parameters in the Biebrza River valley. Ann Warsaw Univ Life Sci-SGGW 43:135-142

Jaszczuk E (2014) Analysis of the climate of the Biebrza Valley in the context of flow-influencing aspects. Diploma thesis, Warsaw University of Life Sciences-SGGW, 65 p

Kotowski W, Jabłońska E, Bartoszuk H (2013) Conservation management in fens: do large tracked mowers impact functional plant diversity? Biol Conserv 167:292-297

Maciorowski G, Mirski P (2014) Habitat alteration enables hybridisation between lesser spotted and greater spotted eagles in north-east Poland. Bird Conserv Int 24:152-161

Mioduszewski W, Okruszko T (2012) Protection of natural wetlands-The examples of conflicts. J Water Land Dev 16:35-42

NWEP (2010) Program Wodno-Środowiskowy Kraju, Krajowy Zarząd Gospodarki Wodnej, Warszawa. (www.kzgw.gov.pl/files/file/Programy/PWSK/Program_wodno-srodowiskowy_ kraju.pdf. Accessed on 13.05.2014)

Okruszko T, Duel H, Acreman M, Grygoruk M, Flörke M, Schneider C (2011) Broad-scale ecosystem services of European wetlands - overview of the current situation and future perspectives under different climate and water management scenarios. Hydrol Sci J 56 (8):1501-1517. doi:10.1080/02626667.2011.631188

Rannow S, Neubert M (eds) (2014) Managing protected areas in Central Europe under climate change. Advances in global change research 58, Springer, Berlin, 308 p. ISBN 978-94-0077960-0

Schneider C, Flörke M, Gerling G, Duel H, Grygoruk M, Okruszko T (2011) The future of European floodplain wetlands under a changing climate. J Water Clim Change 2(2-3):106122. doi: $10.2166 /$ wcc. 2011.020

Wassen MJ, Okruszko T, Kardel I, Chormański J, Świątek D, Mioduszewski W, Bleuten W, Querner EP, El Kahloun M, Batelaan O, Meire P (2006) Eco-hydrological functioning of the Biebrza Wetlands: lessons for the conservation and restoration of deteriorated wetlands. In: Bobbink R, Beltman B, Verhoeven JTA, Wigham DF (eds) Wetlands: functioning, biodiversity conservation and restoration. Springer, Berlin, pp 285-310

Wojciechowski K (1968) Zagadnienia metody bilansu wodnego Thornthwaite'a i Mathera w zastosowaniu do Polski (Problems of Thornthwaite's and Mather's water balance methods in application to Poland). Państwowe Wydawnictwo Naukowe, Warszawa (in Polish)

Zak D, Wagner C, Payer B, Augustin J, Gelbrecht J (2010) Phosphorus mobilization in rewetted fens: the effect of altered peat properties and implications for their restoration. Ecol Appl 20:1336-1349

Żurek S (1984) Relief, geologic structure and hydrography of the Biebrza Valley. Polish Ecological Studies, 10:239-251 